\title{
Legislative Oversight of Brazilian Foreign Policy: An Analysis of Requests for Information and Summonses to Ministers, 1991-2014
}

\author{
Alexandre Spohr* \\ André Luiz Reis da Silva**
}

\begin{abstract}
This article examines oversight over foreign policy-making by the Brazilian National Congress, specifically whether the use of oversight tools at their disposal by Senators and Deputies conform to the 'fire alarm' or 'police patrol' models. This is done by recording and analysing requests for information and summonses to ministers filed in the Chamber of Deputies and the Federal Senate between 1991 and 2014, especially those directed at the Ministry of Foreign Relations. We also compare the use of these instruments in respect of foreign policy to their use in respect of other portfolios. Lastly, analysing the content of these requests and summonses leads to interesting conclusions about how these instruments are used politically, notably in terms of the governmentopposition ideological divide.
\end{abstract}

Keywords: Brazilian Foreign Policy; Legislative Studies; Congressional Oversight; Requests for Information; Summonses to Ministers.

\section{Introduction}

Foreign policy is usually regarded as the exclusive preserve of the executive branch of government. However, as researchers of both legislative studies and foreign policy analysis have expanded their research agendas and combined their efforts, they have begun to recognise the role played by the legislative branch in foreign policy (Mello and Peters 2018). Lawmakers make use of requests for information, summonses to ministers, and other oversight instruments to influence foreign policy, and their contributions to this process need to be understood (Raunio and Wagner 2016). These tools present legislators

\footnotetext{
* Federal University of Rio Grande do Sul (UFRGS), Porto Alegre-RS, Brazil; alexandre.spohr@gmail.com. ORCID iD 0000-0002-3064-3520.

** Federal University of Rio Grande do Sul (UFRGS), Porto Alegre-RS, Brazil; reisdasilva@hotmail.com. ORCID iD 0000-0003-2593-1189.
} 
with an opportunity to play a proactive role in foreign policy-making that has often been undervalued.

Raunio (2014) presents recent trends in the reflection about the legislative role in shaping foreign policy, especially in the USA and Europe. While acknowledging a general belief that parliamentary involvement in foreign policy formation is weak, he notes that parliamentary actors have access to diverse avenues for influencing foreign policy, such as setting ex ante limits, and playing a veto role. He also expresses the need for more research so that comparisons can be drawn and general patterns identified.

Focusing on countries in the Global North, recent issues of European Politics and the British Journal of Politics and International Relations have also dealt with executive - legislative relations in respect of foreign and security policy. According to Mello and Peters (2018), areas requiring further analysis include the informal influence of the legislative function over the policy-making function. In the case of Brazil, we first need to systematically collect and analyse data before proceeding to comparisons with other countries.

Congresses in Latin American countries are generally perceived to be weak and reactive compared to their presidencies (Cox and Morgenstern 2001; Gaylord 2010). According to Amorim Neto and Tafner (2002), delegation is a key element of Latin American democracies. This is especially true of legislative participation in foreign policy formation. According to Latin American and Brazilian specialists, Brazil does not deviate from this pattern.

Restrained by constitutional and practical factors, the National Congress acts mostly through its oversight competencies to influence foreign policy. As in other Western democracies, it makes use of the various oversight instruments at its disposal to examine and influence foreign policy, and to ensure that certain priorities prevail (Raunio and Wagner 2016). According to Herbel (2016), opposition members of Congress do tend to scrutinise government policies and activities when effective oversight tools are at their disposal. However, Llanos and Mustapic (2005) note that at least three factors discourage legislative control over the executive in Brazil. The first is that relations between the various political parties tend to make them prefer co-operation over contestation. Secondly, the Presidency and Congress tend to focus on different but compatible issues. Finally, the legislature does not have sufficient powers to exercise effective control over the executive.

In order to develop an understanding of how the Brazilian Congress deals with foreign policy issues, this article focuses on two instruments of oversight: requests for information, and the summoning of ministers. It seeks to establish whether Senators and Deputies make use of these oversight tools in different ways when dealing with foreign policy. This comparison will help to develop research in this area, in line with the suggestions by Mello and Peters (2018). It compares requests for information about foreign policy with requests for information about other portfolios, notably the economy, health, education and defence. This instrument provides Congress not only with a means of examining executive actions - like the approval of treaties and the nomination of authorities - but also to promote its own policy agenda.

The characterisation of legislative oversight as either 'fire alarms' or 'police patrols' (McCubbins and Schwartz 1984) is particularly relevant. Our empirical data and analysis 
allow us to determine which factors stand out and which patterns prevail in legislative engagement with foreign policy. Until now, researchers have tended to describe the role of legislators in respect of foreign policy as 'fire alarms', or reactive (see, for example, Lagassé and Saideman 2016). However, our data points to a different conclusion.

Our belief, based on previous studies, analyses of other oversight tools and current data, is that, while showing some particularities, interventions in foreign policy are influenced by general legislative dynamics, especially the contestations among parties.

Therefore, despite the importance of political constituents in driving their representatives to oversee the executive, the latter are also engaged by issues beyond their constituencies. Foreign policy can be discussed in the National Congress in terms of a governmentopposition logic, and can be mobilised by Deputies and Senators in both 'fire alarm' and 'police patrol' strategies. In recent years, highly controversial political issues have provoked the intense interest of Brazilian lawmakers, mobilising them into active oversight of the executive. This has been accompanied by a growth in the general political debate about Brazilian foreign policy.

This study is based on the collection and analysis of data from the two houses of the Brazilian Congress - the Chamber of Deputies and the Federal Senate. By compiling data about all the issues raised by members of the National Congress, and identifying underlying patterns, it allows us to ascertain whether foreign policy stands out, and to establish which of the two main modes of oversight - 'fire alarm' or 'police patrol' - prevails. An in-depth analysis of requests and summonses involving the Ministry of Foreign Relations (Itamaraty) will deepen our understanding of the use of these instruments. The empirical and analytical contributions of other researchers will shed further light on this issue.

\section{Congressional oversight over foreign policy}

Relations between the executive and legislative branches of government are an essential element of democracy, but play themselves out in different ways in different countries. In Brazilian democracy, the range of political parties represented in the National Congress lend a special dynamic to legislative-executive relations. According to Abranches (1988), the Brazilian political system operates according to a logic of 'coalition presidentialism' This means that elected presidents need to negotiate the establishment of ministries and the allocation of resources with other parties in the two Houses of the Brazilian National Congress. In this system, the Presidency faces great challenges in dealing with a highly heterogeneous Congress. These difficulties have been evident in the two impeachment processes that have taken place since the adoption of the 1988 Constitution.

Given that the legislature houses representatives of many different parties, with widely diverging beliefs and interests, we need to understand how it functions. There are two major lines of thought on this score. Some analysts, like Pereira and Rennó (2013), focus on the quest by members of Congress for re-election. They regard lawmakers as rational individual actors seeking to maximise their interests, and please their constituents. For them, legislative decisions are the result of cost-benefit analyses. Others focus on the contestations among political parties. Among them are Figueiredo and Limongi (1999), who have 
studied the roles played by parties in determining the conduct of members of Congress, and analysed party discipline in the Chamber of Deputies.

This article follows the second line of thought. If the first was valid, there would be no difference in the patterns of engagement with foreign policy and other areas of policy, as the former does not directly attract voter support. Therefore, one has to examine other motivations. We believe the major driver of attempted oversight of foreign policy formation and implementation lies in the contestation between the governing party and opposition parties. This postulate chimes with other research on the issue, such as Oktay's findings (2018) about party-political influences over security policy, and Raunio and Wagner's examination (2016) of West European politics.

When dealing with foreign policy, the legislature tends to assume an oversight role rather than a decision-making one. Kaiser (1988) classifies patterns of oversight as manifest or latent, official or unofficial, direct or indirect, and adversarial or supportive. In this article, we examine two formal instruments for holding the executive to account. Depending on the case, they may be used for the purposes of attempted control or of valuation. Adversarial oversight will usually be exercised by members of the opposition, as a means of influencing executive decision-making, or at least interrogating the course of action the executive has chosen to pursue.

In the course of challenging the assumption that the US Congress has abdicated from its obligation to exercise oversight over the Presidency, McCubbins and Schwartz (1984) propose a typology for classifying and analysing these sorts of activities. They believe oversight may work like 'police patrols' - constantly and visibly - or like 'fire alarms' - reacting to or being activated by certain events. Some analysts - notably Lemos (2005b) - believe the second holds true for the Brazilian Congress in dealing with foreign policy, and that Latin American legislatures in general are reactive in overseeing their Presidencies. However, the instruments analysed in this article allow the legislative to act proactively, or in 'police patrol' mode. By analysing their actual use, we will discover which mode prevails.

The precise moments when oversight mechanisms are used can also be relevant to understanding the intentions of their users, as well as their efficacy. In this respect, instruments of oversight can be classified as either ex ante or ex post (Lupia 2003). While most tools operate ex post facto, i.e., after a certain action, requests for information and summonses to ministers may be used both before and after foreign policy decisions and events. Although they tend to be employed after certain events, these instruments also allow lawmakers to try to influence decision-making while it is taking place. This typifies an ex ante strategy, in which members of Congress demand answers about certain issues, or summon ministers to provide information about and discuss their activities.

\section{Instruments of congressional oversight in Brazil}

In an effort to understand how foreign policy is made, and how those responsible for it are held accountable, many researchers have focused on oversight instruments and strategies available to legislatures. These studies try to shed light on a field of politics that has only recently received increased attention in the media. There is already a considerable body 
of research on the role played by legislative powers in foreign policy-making in developed countries, including the EU (Batjay 2015; European Parliament 2015; Fowler 2015; Kaiser 1977; Mello and Peters 2018; Raunio and Wagner 2016).

In respect of Brazil, Lima and Santos (2001) have analysed the oversight of National Congress over Brazil's trade policy, and defined its role as one of abdication. However, our analysis, which focuses on foreign policy, differs from this interpretation, as in this instance the oversight instruments available to members of Congress are sometimes used in proactive ways as well.

The Constitution of the Federative Republic of Brazil (Brazil 2016) confers extensive powers on the executive branch in respect of foreign policy. For example, Article 84 states that the Presidency is responsible for signing treaties, conventions and international Acts. However, it also provides the legislative branch with significant powers of oversight, aimed at holding the Presidency accountable for its decisions and activities in all areas, including foreign policy. For example, Article 49 gives the Congress powers to take decisions about treaties, conventions and international Acts that may result in costs to the national heritage.

The primary loci for reflection on foreign policy issues in each House of the Brazilian National Congress are their respective Committees of Foreign Relations and National Defence (Silva 2012). Members of these committees are able to discuss foreign policy in depth, and oversee Itamaraty. This is not necessarily what happens. However, many oversight tools are channelled through the committee system. Also, according to Lin (2015), legislative committees in general tend to play a significant role in influencing the outcomes of legislative decisions.

According to their internal rules (Chamber of Deputies 2012; Federal Senate 2011), the Brazilian Chamber of Deputies and Federal Senate are entitled to use common and specific instruments to oversee the Presidency and its subordinate institutions. Both Deputies and Senators can request information from ministers, summon them to answer questions, suggest actions (issue directives), establish commissions to investigate and evaluate executive projects, or issue congratulatory or critical notes. Moreover, both Houses play a major role in approving treaties, without which the Presidency is not allowed to ratify them. Finally, the Federal Senate has to approve various authorities nominated by the executive. Since the adoption of the 1988 Constitution, the use of oversight instruments has increased (Lemos 2005a).

The Congress is responsible for taking definitive decisions about treaties, allowing the Presidency to ratify them or not. Therefore, it reacts to decisions made by the executive, mostly in 'fire alarm' mode. This form of influence over foreign policy has received the attention of numerous Brazilian scholars (Diniz 2009; Diniz and Ribeiro 2008; Silva and Spohr 2016). According to the empirical data produced by these studies, treaties have almost never been rejected in either House of the Congress. However, there have been significant delays in approving treaties, mostly those involving controversial issues (Silva and Spohr 2016). This tends to be interpreted as disinterest, but can also indicate that members of Congress follow their own agendas when dealing with foreign policy. Even if 
almost every treaty is approved, the delay in the decision can reveal the degree to which the issue is controversial among lawmakers.

The Federal Senate has the competence to approve or reject the nomination of authorities, especially those responsible for Brazilian permanent missions abroad, thereby reacting to executive decisions. This form of legislative oversight has received growing attention in recent years (Lemos and Llanos 2008; Lemos 2010). Its pattern of use endorses the assumption that Senators follow a similar logic while deciding on the nomination of ambassadors and other authorities, as almost no nominations have been rejected since 1988. ${ }^{1}$ Therefore, this instrument is largely used in 'fire alarm' mode, but also allows lawmakers to challenge government decisions, especially when influenced by governmentopposition dynamics.

The tools at the disposal of members of Congress for challenging all aspects of the legislative-executive agenda presents us with an opportunity to compare the handling of foreign policy to that of other policy areas. Also, these instruments are not only employed in respect of executive decisions and actions, but can also form part of party contestation and strategies in the Congress. For example, lawmakers can issue directives to encourage the executive to adopt a certain course of action. Anastasia, Mendonça and Almeida (2012) have analysed the use of this tool in respect of foreign policy, and discovered that lawmakers tend to issue directives individually, focusing on specific elements to be addressed by Itamaraty. Members of Congress therefore use this instrument in respect of the Presidency in 'police patrol' mode.

The two tools on which this article focuses, namely requests for information from and the summoning of ministers, also allow members of Congress to oversee the executive in a more proactive way. They were chosen due to the lack of a comprehensive collection and thorough analysis of data about their use, and how this compares to their use in other policy areas. Lemos (2005a) and Santos (2005) have already analysed the use of these instruments in the Brazilian legislature, the latter by focusing on oversight of the military. According to these two authors, there are important particularities in the use of these tools. First, requests for information allow Deputies and Senators to pursue their agendas individually, and to have specific questions answered. According to Jensen, Proksch and Slapin (2013), besides their oversight function, parliamentary questions also serve the purpose of making known the questioner's view on a particular issue. Second, summoning a minister represents a more serious approach to oversight. Overall, Lemos (2005a) notes that these two tools are used in 'fire alarm' mode. However, the data in this article points to a different conclusion.

\section{The quantitative analysis of general data}

We will analyse how members of the Brazilian Parliament uses requests for information and summonses to ministers to influence foreign policy. We will look at the use of these instruments in both houses of the National Congress, and try to identify patterns of use. We have collected data for the Chamber of Deputies and the Federal Senate from their of- 
ficial databases for the six legislative terms ( $49^{\text {th }}$ to $54^{\text {th }}$, from 1991 to 2014 ) following the promulgation of the Constitution of the Federative Republic of Brazil in 1988 (Chamber of Deputies 2018, Federal Senate 2018). ${ }^{2}$ The $55^{\text {th }}$ legislative term has not been included because it has been subject to new forms of instability, which cannot yet be thoroughly analysed.

This data is analysed to verify whether these instruments are used in the same way to oversee foreign policy and other policy areas. In order to do so, we examine how often they are employed in each policy area, and how they are mobilised by the opposition and by members of the government coalition. Due to differences in the numbers of requests, these patterns need to be analysed in both absolute and relative terms in order to allow comparisons across policy areas.

We then move towards a qualitative analysis of requests of information and summonses to ministers in respect of foreign policy. This allows us to ascertain whether those instruments were used in reactive or proactive ways, as fire alarms or police patrols. The content and context of the requests allow us to understand whether members of Congress try to influence decisions while they are being made, or afterwards. The frequency of themes in the use of these tools will also be analysed in order to establish which topics are mobilised the most.

\section{Requests for information}

According to the internal rules of both Houses of the National Congress (Chamber of Deputies 2012; Federal Senate 2011), their members can present requests for information to help them draft new legislation, or exercise their oversight duties. In respect of the latter, they can ask ministers and other officials with equivalent status to reply to their questions, or to produce documents related to the activities of ministries and other government bodies. These requests have to be approved by the Board of the respective House. If no answer is provided within 30 days, or false information is provided, the minister concerned is deemed to have committed a crime of responsibility, which attracts legal sanction.

Members of Congress can use requests for information to extract information from the executive branch, or to call it to account for its actions. The relatively simple procedures for submitting requests for information allow any deputy or senator to have their concerns addressed, with some space for the leadership of each House to vet undesired requests. The large number of requests for information in the period under review (more than 26000 in the Chamber of Deputies, and almost 5000 in the Federal Senate) shows how often and how easily members of Congress have resorted to using this instrument.

Motivations for requests may vary. Opposition members use them to challenge policies, or to extract more information. Members of the government coalition use them to publicise certain policies among fellow lawmakers or members of the public, and even to gain information that is not otherwise available via informal channels. 
Table 1: Requests for information filed in the Chamber of Deputies

\begin{tabular}{|c|c|c|c|c|c|c|c|c|c|c|c|}
\hline & \multicolumn{6}{|c|}{ Legislative Term } & \multirow{2}{*}{ Total } & \multirow{2}{*}{$\begin{array}{c}\text { Standard } \\
\text { Deviation }\end{array}$} & \multirow{2}{*}{ Government } & \multirow{2}{*}{ Opposition } & \multirow{2}{*}{ Committee } \\
\hline & $49^{\text {th }}$ & $50^{\text {th }}$ & $51^{\text {st }}$ & $52^{\text {nd }}$ & $53^{\text {rd }}$ & $54^{\text {th }}$ & & & & & \\
\hline Economy & 854 & 901 & 772 & 424 & 371 & 321 & 3643 & 263 & $30 \%$ & $66.2 \%$ & $3.8 \%$ \\
\hline Health & 178 & 390 & 465 & 347 & 645 & 445 & 2470 & 153 & $46.3 \%$ & $50.8 \%$ & $2.9 \%$ \\
\hline $\begin{array}{l}\text { Mines and } \\
\text { Energy }\end{array}$ & 240 & 266 & 472 & 407 & 524 & 502 & 2411 & 122 & $29.8 \%$ & $66 \%$ & $4.3 \%$ \\
\hline Education & 128 & 210 & 255 & 203 & 305 & 425 & 1526 & 102 & $34.5 \%$ & $63.4 \%$ & $2.1 \%$ \\
\hline Justice & 191 & 171 & 213 & 292 & 265 & 300 & 1432 & 54.4 & $34.3 \%$ & $60.1 \%$ & $5.6 \%$ \\
\hline Defense & 268 & 193 & 178 & 199 & 384 & 142 & 1364 & 87.1 & $24.3 \%$ & $72.7 \%$ & $3 \%$ \\
\hline Planning & 62 & 436 & 175 & 152 & 171 & 266 & 1262 & 128 & $39.5 \%$ & $57.8 \%$ & $2.6 \%$ \\
\hline Social Security & 208 & 349 & 362 & 155 & 88 & 50 & 1212 & 131 & $28.8 \%$ & $69.6 \%$ & $1.6 \%$ \\
\hline Transports & 144 & 142 & 207 & 170 & 242 & 211 & 1116 & 40.4 & $35.3 \%$ & $61.7 \%$ & $3 \%$ \\
\hline Environment & 143 & 186 & 213 & 185 & 245 & 129 & 1101 & 43.1 & $44 \%$ & $51.9 \%$ & $4.1 \%$ \\
\hline Communications & 130 & 202 & 262 & 184 & 186 & 111 & 1075 & 53.9 & $40.7 \%$ & $52.3 \%$ & $6.9 \%$ \\
\hline Agriculture & 131 & 140 & 169 & 121 & 155 & 64 & 780 & 36.6 & $32.6 \%$ & $63.4 \%$ & $4 \%$ \\
\hline Cities & 0 & 0 & 120 & 76 & 214 & 243 & 653 & 104 & $33.3 \%$ & $65 \%$ & $1.7 \%$ \\
\hline Labor & 129 & 71 & 120 & 91 & 183 & 55 & 649 & 46.2 & $18.3 \%$ & $80.4 \%$ & $1.4 \%$ \\
\hline $\begin{array}{l}\text { Agrarian } \\
\text { Development }\end{array}$ & 0 & 36 & 99 & 96 & 268 & 133 & 632 & 93 & $19.5 \%$ & $77.1 \%$ & $3.3 \%$ \\
\hline $\begin{array}{l}\text { Development, } \\
\text { Industry and } \\
\text { Trade }\end{array}$ & 15 & 84 & 171 & 145 & 99 & 92 & 606 & 54 & $29.5 \%$ & $64 \%$ & $6.5 \%$ \\
\hline $\begin{array}{l}\text { Science and } \\
\text { Technology }\end{array}$ & 28 & 31 & 72 & 109 & 207 & 92 & 539 & 65.9 & $36.1 \%$ & $61.5 \%$ & $2.4 \%$ \\
\hline $\begin{array}{l}\text { Foreign } \\
\text { Relations }\end{array}$ & 82 & 72 & 84 & 98 & 99 & 83 & 518 & 10.4 & $24.3 \%$ & $68.7 \%$ & $6.9 \%$ \\
\hline $\begin{array}{l}\text { Social } \\
\text { Development }\end{array}$ & 162 & 0 & 0 & 102 & 123 & 124 & 511 & 68.8 & $23 \%$ & $75.2 \%$ & $1.8 \%$ \\
\hline Chief of Staff & 12 & 44 & 71 & 116 & 173 & 80 & 496 & 56.4 & $14.9 \%$ & $79.7 \%$ & $5.4 \%$ \\
\hline Total & 4602 & 5425 & 4189 & 4813 & 4067 & 3357 & 26453 & & $32.5 \%$ & $63.9 \%$ & $3.6 \%$ \\
\hline Average & 118 & 139 & 107 & 123 & 104 & 86 & 678 & & & & \\
\hline Median & 83 & 99 & 91 & 71 & 31 & 17 & 392 & & & & \\
\hline
\end{tabular}

Table 1 shows that members of the Chamber of Deputies submitted the most requests for information during the period of analysis. Almost a third were directed at the Ministries of the Economy (including the General Bank of Brazil), Health, and Mines and Energy. However, the numbers of requests directed at each of these ministries vary considerably. While requests for information to the Ministry of the Economy decreased, those for the Ministries of Health and Mines and Energy increased. This might have resulted from growing attention to economic issues in the 1990s, due to efforts to combat inflation. Meanwhile, constituency-related issues gained importance. These requests were directed at the Ministries of Health, Mines and Energy, Education, Transport, and Planning, among others, which might have inflated their numbers. 
The Ministry of Foreign Relations appears as the $18^{\text {th }}$ most questioned of more than 40 ministries. It climbed a few positions from the first three legislative terms to the later three, receiving more attention than other ministries during the Presidencies of the Workers' Party (PT). Requests directed at this ministry (516) account for $2 \%$ of the total, which is lower than the average but higher than the median.

Requests directed at Itamaraty were steadier than others throughout the periods under review. Nevertheless, their numbers were lower on average than for all the other ministries. This means that, while foreign policy was not the policy area of greatest concern to members of the Chamber of Deputies, attracting fewer requests than economics, health, energy, education, justice and defence, it provoked as much interest as science and technology, as well as social development. The steady pattern of requests for information indicates a continuous interest in this area, which contrasts with other ministries. Indeed, the Ministry of Foreign Relations presents by far the smallest standard deviation among the 30 ministries that received the most requests.

Opposition Deputies filed almost twice as many requests as coalition Deputies. This corroborates the previous findings of the literature on the presidential system in Brazil, which holds that executive-legislative relations are stabilised by negotiations among parties. Therefore, Congressional instruments of oversight are useful for assessing dissent in Congress, as any deputy can present a request for information, and opposition members can use them to try to influence decision-making. Requests by committees totalled 959, presenting a trend of growth in recent legislative terms.

Requests for information directed at the Ministry of Foreign Relations show a similar pattern in respect of their source. Requests by allies comprised about a third of those submitted by members of the opposition - 126 against 355 - which was close to average. While this was also the case for Economy, the policy area at the top of the table, Health, in second place, showed the greatest deviation, with allies submitting $46 \%$ of requests for information, and opposition members almost $51 \%$.

Regarding requests for information filed by committees, the Ministry of Foreign Relations appears in ninth place. This might indicate that this ministry is often included in the workflows of committees. Committees that requested information included the Committee of Foreign Relations and National Defence (CREDN), but also the Human Rights and Financial Oversight committees. It also comes as no surprise that requests to the Ministry of Foreign Relations represent $40.7 \%$ of requests made by the CREDN, almost more than double the number of requests directed at the Ministry of Defence - 22 against 10 .

Senators submitted significantly less requests for information than Deputies. This is largely due to the great disparity in the size of each House - 513 Deputies versus 81 Senators - but there might be other reasons as well. The three ministries that received the most requests for information were the same for both Houses: the Ministries of the Economy, Mines and Energy, and Health. Together, they attracted more than a third of requests in the period under review. Unlike some Deputies, no Senators inflated the numbers of requests to any ministries due to pressures from their constituencies. 
Table 2: Requests for information filed in the Federal Senate

\begin{tabular}{|c|c|c|c|c|c|c|c|c|c|c|c|}
\hline & \multicolumn{6}{|c|}{ Legislative Term } & \multirow{2}{*}{ Total } & \multirow{2}{*}{$\begin{array}{l}\text { Standard } \\
\text { Deviation }\end{array}$} & \multirow{2}{*}{ Government } & \multirow{2}{*}{ Opposition } & \multirow{2}{*}{ Committee } \\
\hline & $49^{\text {th }}$ & $50^{\text {th }}$ & $51^{\text {st }}$ & $52^{\text {nd }}$ & $53^{\text {rd }}$ & $54^{\text {th }}$ & & & & & \\
\hline Economy & 212 & 299 & 138 & 219 & 89 & 108 & 1065 & 79.9 & $44.2 \%$ & $53.4 \%$ & $2.4 \%$ \\
\hline $\begin{array}{l}\text { Mines and } \\
\text { Energy }\end{array}$ & 51 & 57 & 55 & 104 & 57 & 95 & 419 & 23.3 & $41.7 \%$ & $54.2 \%$ & $4.2 \%$ \\
\hline Health & 21 & 35 & 39 & 102 & 53 & 60 & 310 & 28.2 & $35.5 \%$ & $59.4 \%$ & $5.2 \%$ \\
\hline Justice & 24 & 31 & 55 & 86 & 49 & 56 & 301 & 21.9 & $42.5 \%$ & $50.2 \%$ & $7.4 \%$ \\
\hline Defense & 35 & 38 & 24 & 88 & 39 & 39 & 263 & 22.4 & $39.6 \%$ & $55.5 \%$ & $4.9 \%$ \\
\hline Planning & 14 & 114 & 20 & 54 & 25 & 27 & 254 & 37.7 & $51.6 \%$ & $45.7 \%$ & $2.8 \%$ \\
\hline Transports & 17 & 29 & 21 & 52 & 23 & 49 & 191 & 15 & $51.1 \%$ & $44.4 \%$ & $4.5 \%$ \\
\hline Communications & 27 & 24 & 16 & 28 & 23 & 38 & 156 & 7.2 & $43.4 \%$ & $41.4 \%$ & $15.2 \%$ \\
\hline $\begin{array}{l}\text { Foreign } \\
\text { Relations }\end{array}$ & 17 & 16 & 15 & 42 & 36 & 27 & 153 & 11.5 & $31.1 \%$ & $46.4 \%$ & $22.5 \%$ \\
\hline Education & 17 & 19 & 20 & 47 & 21 & 27 & 151 & 11.2 & $18.5 \%$ & $68.5 \%$ & $12.9 \%$ \\
\hline Social Security & 13 & 38 & 19 & 46 & 14 & 19 & 149 & 13.8 & $47.3 \%$ & $50 \%$ & $2.7 \%$ \\
\hline Agriculture & 32 & 37 & 16 & 31 & 16 & 17 & 149 & 9.5 & $44.3 \%$ & $53 \%$ & $2.7 \%$ \\
\hline Chief of Staff & 2 & 15 & 1 & 101 & 14 & 16 & 149 & 37.9 & $9.4 \%$ & $85.2 \%$ & $5.4 \%$ \\
\hline $\begin{array}{l}\text { Development, } \\
\text { Industry and } \\
\text { Trade }\end{array}$ & 7 & 14 & 18 & 50 & 17 & 42 & 148 & 17.2 & $44.8 \%$ & $51.7 \%$ & $3.4 \%$ \\
\hline Environment & 7 & 30 & 8 & 46 & 24 & 29 & 144 & 14.8 & $42.4 \%$ & $52.8 \%$ & $4.9 \%$ \\
\hline $\begin{array}{l}\text { Agrarian } \\
\text { Development }\end{array}$ & 0 & 11 & 22 & 35 & 21 & 18 & 107 & 11.7 & $33.3 \%$ & $57.1 \%$ & $9.5 \%$ \\
\hline Labor & 19 & 11 & 16 & 39 & 9 & 11 & 105 & 11.2 & $31.5 \%$ & $64.9 \%$ & $3.6 \%$ \\
\hline $\begin{array}{l}\text { National } \\
\text { Integration }\end{array}$ & 18 & 3 & 13 & 21 & 14 & 16 & 85 & 6.2 & $42.5 \%$ & $50 \%$ & $7.5 \%$ \\
\hline $\begin{array}{l}\text { Social } \\
\text { Development }\end{array}$ & 16 & 0 & 0 & 33 & 5 & 12 & 66 & 12.6 & $17.2 \%$ & $81 \%$ & $1.7 \%$ \\
\hline $\begin{array}{l}\text { Science and } \\
\text { Technology }\end{array}$ & 4 & 6 & 7 & 24 & 8 & 15 & 64 & 7.5 & $34.4 \%$ & $64.1 \%$ & $1.6 \%$ \\
\hline Total & 593 & 891 & 556 & 1413 & 630 & 877 & 4960 & & $39.1 \%$ & $55.5 \%$ & $5.4 \%$ \\
\hline Average & 24.5 & 32.9 & 22.2 & 38.2 & 16.6 & 22.5 & 127 & & & & \\
\hline Median & 17 & 16 & 16 & 24 & 8.5 & 16 & 66 & & & & \\
\hline
\end{tabular}

Table 2 shows that the Ministry of Foreign Relations occupied ninth place in the ranking of requests by Senators, with no particular trend in terms of its evolution over legislative terms. Its portion of the overall number of requests was a bit larger than in the Chamber of Deputies - its 153 requests represent almost 3.1\% of the total. Other ministries, such as Education, Social Welfare, and Agriculture, attracted fewer requests. In contrast with the pattern among Deputies, requests made by Senators fluctuated more over the various legislative terms, displaying a standard deviation of 11.5 , compared with smaller deviations for other ministries. However, the number of requests directed at Itamaraty was still significantly smaller than those of the top recipients, such as Economy. 
In the Senate, opposition members also submitted the most requests for information, but with a smaller difference - 1935 against 2 750. As in the Chamber of Deputies, the number of requests submitted by committees increased in later terms, reaching a total of 266. In this instance, coalition Senators filed more requests to certain ministries - notably Communications, Transport and Planning - than opposition Senators.

The Ministry of Foreign Relations presents a similar pattern to the overall distribution of requests among allies and opponents -47 against 71 . However, during the $50^{\text {th }}$ legislative term, allied Senators submitted far more requests than opposition Senators (13 against three), with a tie during the $54^{\text {th }}$ session (11 each). Requests for information submitted by Senate committees formed an important portion of the requests directed at Itamaraty - 34, or $22 \%$. Again, the committee that submitted the most requests to this ministry was the Committee of Foreign Relations and National Defence (29), and this committee directed most of its requests to the Ministry of Foreign Relations (44.6\%). Defence was in second place, accounting for $16.9 \%$ (11) of requests by Senate committees.

\section{Summonses to ministers}

The internal rules of both Houses of the Brazilian National Congress also set out the norms and procedures for summoning ministers. While both requests for information and summonses are aimed at extracting information from ministers, and holding them to account, they are used in different ways. Summonses are restricted to more sensitive matters, when there is a greater need for dialogue with the ministers concerned in order to evaluate and possibly adapt the chosen course of action. However, the opposition can use this instrument to dissuade ministers from adopting a certain course of action, or to state their position in a more assertive way, while government allies may use them to allow ministers to vouch for their projects, enlighten members of Congress about their current activities, or even to gain information they are not able to access via intra-party mechanisms.

According to the internal rules of the Brazilian Chamber of Deputies (2012) and Federal Senate (2011), hearings with ministers take place following a request by a deputy, senator or committee, or when a minister arranges a hearing with the Presidency of one of the Houses. In this article, we focus on the summoning of ministers by members of Congress or committees, as a way of measuring how they seek to influence executive behaviour. When a summons is filed in one of the Houses, it is put to a vote by the Presidency. Upon approval, it is sent to the minister in question together with the subject on which he or she will have to provide information. Hearings have to take place within 30 days - otherwise, the minister is deemed to have committed a crime of responsibility.

The particularities of this instrument are probably the reason why there were far fewer summonses than requests for information in the period under review. Although ministers are officially invited instead of summoned, this instrument can create greater tensions between the branches of government, as ministers are often not too happy to be at the beck and call of lawmakers. Also, information in the Brazilian Chamber of Deputies database about legislative proposals in the 1991-1998 period is not complete, thus introducing the need to reduce the period of analysis. 
During the four legislative terms between 1999 and 2014, there were 1054 petitions for summoning ministers. The top five ministers accounted for almost half (46.6\%) of the total. They were the ministers of the Economy, Justice, Mines and Energy, Foreign Relations and Planning. The Minister of the Economy received the most summonses, more than twice those received by the Minister of Planning - 164 and 71 respectively.

There were far more summonses in the $54^{\text {th }}$ legislative term than in the others $(1.86$ times that of the $53^{\text {rd }}$ ). This coincides with the first term of Dilma Rousseff, with a more or less even distribution among the years (only in 2011 were there less than 100 summonses). Dilma, who was impeached in 2016 after her re-election in 2014, experienced some turbulence during her first term, such as the June protests in 2013, various corruption scandals, and contestations from within her heterogeneous coalition.

Table 3: Summonses of Ministers filed in the Chamber of Deputies

\begin{tabular}{|c|c|c|c|c|c|c|c|c|c|}
\hline & \multicolumn{4}{|c|}{ Legislative Term } & \multirow{2}{*}{ Total } & \multirow{2}{*}{$\begin{array}{l}\text { Standard } \\
\text { Deviation }\end{array}$} & \multirow{2}{*}{ Government } & \multirow{2}{*}{ Opposition } & \multirow{2}{*}{ Committee } \\
\hline & $51^{\text {st }}$ & $52^{\text {nd }}$ & $53^{\text {rd }}$ & $54^{\text {th }}$ & & & & & \\
\hline Economy & 24 & 41 & 42 & 57 & 164 & 14.8 & $17.8 \%$ & $82.2 \%$ & $0 \%$ \\
\hline Justice & 12 & 28 & 11 & 25 & 76 & 8.2 & $19.2 \%$ & $80.8 \%$ & $0 \%$ \\
\hline Mines and Energy & 13 & 19 & 16 & 24 & 72 & 5 & $25.7 \%$ & $74.3 \%$ & $0 \%$ \\
\hline Foreign Policy & 8 & 29 & 21 & 19 & 77 & 9 & $10.5 \%$ & $88.2 \%$ & $1.3 \%$ \\
\hline Foreign Relations & 8 & 25 & 20 & 18 & 71 & 7.1 & $11.4 \%$ & $87.1 \%$ & $1.4 \%$ \\
\hline International Affairs & 0 & 4 & 1 & 1 & 6 & 1.7 & $0 \%$ & $100 \%$ & $0 \%$ \\
\hline Planning & 5 & 12 & 20 & 27 & 64 & 9.6 & $20.3 \%$ & $79.7 \%$ & $0 \%$ \\
\hline Chief of Staff & 2 & 8 & 21 & 26 & 57 & 11.4 & $15.8 \%$ & $82.5 \%$ & $1.8 \%$ \\
\hline Health & 16 & 11 & 8 & 21 & 56 & 8 & $19.6 \%$ & $80.4 \%$ & $0 \%$ \\
\hline Defense & 6 & 18 & 18 & 10 & 52 & 7.4 & $23.1 \%$ & $76.9 \%$ & $0 \%$ \\
\hline Agriculture & 9 & 6 & 6 & 21 & 42 & 5.6 & $31.7 \%$ & $68.3 \%$ & $0 \%$ \\
\hline Agrarian Development & 6 & 9 & 7 & 11 & 33 & 1.8 & $31.3 \%$ & $68.8 \%$ & $0 \%$ \\
\hline Development, Industry and Trade & 2 & 10 & 3 & 16 & 31 & 9.5 & $12.9 \%$ & $87.1 \%$ & $0 \%$ \\
\hline Social Security & 8 & 6 & 7 & 6 & 27 & 1.4 & $11.1 \%$ & $88.9 \%$ & $0 \%$ \\
\hline Labor & 4 & 6 & 2 & 15 & 27 & 5.6 & $3.7 \%$ & $96.3 \%$ & $0 \%$ \\
\hline Environment & 3 & 5 & 6 & 12 & 26 & 3.9 & $28 \%$ & $72 \%$ & $0 \%$ \\
\hline Communications & 4 & 4 & 7 & 8 & 23 & 2.1 & $0 \%$ & $100 \%$ & $0 \%$ \\
\hline Total & 142 & 248 & 232 & 432 & 1054 & & $17.3 \%$ & $82.5 \%$ & $0.2 \%$ \\
\hline Average & 7.8 & 14.2 & 13.1 & 23.7 & 58.8 & & & & \\
\hline Median & 3 & 5 & 3 & 10 & 22 & & & & \\
\hline
\end{tabular}

Table 3 shows that the Minister of Foreign Relations is the fourth most summoned by the Chamber of Deputies, representing $7 \%$ of the total. This increase compared to requests for information might point to the strategy employed by Deputies in respect of foreign policy. Instead of asking for information, Deputies seem to prefer requiring ministers to attend hearings in order to allow a fuller discussion of their areas of concern. Given that foreign policy is a field in which less attention is paid to projects and issues, Deputies tend to prefer more thorough debates to simple written answers to questions. 
Deputies have also used this instrument to summon the advisor for International Affairs, an important actor in the formulation of foreign policy during the PT administrations. ${ }^{3}$ He was never asked for information.

Most Deputies filing summonses to ministers are members of the opposition - about $80 \%$ of requests for summonses in every legislative term. The only exceptions were the Secretariat of Ports - where government allies summoned the secretary twice, and the opposition only once - and the Ministries of Science and Technology and Culture, which presented a tie. In contrast with requests for information, committees filed almost no summonses of minister (only two), but usually served as conduits.

Requests to the two authorities with ministry status regarding foreign policy followed the same pattern of distribution regarding authorship - $88.2 \%$ of the summonses were filed by opposition Deputies. More than half were filed by Deputies from the Brazilian Social Democracy Party (PSDB), especially during President Lula's two administrations, which accounted for 30 of the 77 requests. The PSDB was responsible for all summonses to the advisor for International Affairs in the period under review, and almost $34 \%$ of all summonses to ministers. This corresponds with the broader partisan dispute between the PT and PSDB following the 2003 presidential elections.

Senators filed far fewer summonses to ministers in the period under review. Many years went by with no summonses by Senators, especially during the last two legislative terms. Again, the Ministry of the Economy received the most summonses from Senators, comprising almost a fifth of the total. The variation across the legislative terms was considerable, with the two first terms accounting for 20 of the 24 summonses to the ministry, probably due to the importance of the battle against inflation in the 1990s.

Table 4: Summonses of ministers filed in the Federal Senate

\begin{tabular}{|c|c|c|c|c|c|c|c|c|c|c|}
\hline & \multicolumn{6}{|c|}{ Legislative Term } & \multirow{2}{*}{ Total } & \multirow{2}{*}{ Government } & \multirow{2}{*}{ Opposition } & \multirow{2}{*}{ Committee } \\
\hline & $49^{\text {th }}$ & $50^{\text {th }}$ & $51^{\text {st }}$ & $52^{\text {nd }}$ & $53^{\text {rd }}$ & $54^{\text {th }}$ & & & & \\
\hline Economy & 10 & 10 & 2 & 2 & 0 & 0 & 24 & $34.8 \%$ & $65.2 \%$ & $0 \%$ \\
\hline Foreign Relations & 1 & 0 & 6 & 2 & 0 & 2 & 11 & $9.1 \%$ & $81.8 \%$ & $9.1 \%$ \\
\hline Justice & 2 & 1 & 1 & 4 & 2 & 0 & 10 & $30 \%$ & $70 \%$ & $0 \%$ \\
\hline Planning & 0 & 9 & 0 & 0 & 1 & 0 & 10 & $80 \%$ & $20 \%$ & $0 \%$ \\
\hline Health & 1 & 3 & 3 & 2 & 2 & 0 & 11 & $40 \%$ & $60 \%$ & $0 \%$ \\
\hline Agriculture & 3 & 3 & 1 & 1 & 0 & 0 & 8 & $50 \%$ & $50 \%$ & $0 \%$ \\
\hline Mines and Energy & 2 & 1 & 1 & 3 & 1 & 0 & 8 & $50 \%$ & $50 \%$ & $0 \%$ \\
\hline Labor & 4 & 1 & 0 & 2 & 0 & 0 & 7 & $42.9 \%$ & $57.1 \%$ & $0 \%$ \\
\hline Chief of Staff & 0 & 0 & 0 & 4 & 1 & 0 & 5 & $0 \%$ & $100 \%$ & $0 \%$ \\
\hline Agrarian Development & 0 & 1 & 1 & 3 & 0 & 0 & 5 & $40 \%$ & $60 \%$ & $0 \%$ \\
\hline Total & 32 & 36 & 22 & 32 & 9 & 3 & 134 & $33.6 \%$ & $65.7 \%$ & $0.7 \%$ \\
\hline Average & 1.1 & 1.4 & 0.8 & 1.2 & 0.3 & 0.1 & 4.9 & & & \\
\hline Median & 0 & 1 & 0 & 1 & 0 & 0 & 3 & & & \\
\hline
\end{tabular}

Source: Federal Senate (2018).

Table 4 shows that the minister of Foreign Relations was the second most summoned, accounting for more than $8 \%$ of all summonses by Senators. However, there was no ho- 
mogeneity among legislative terms, with a predominance of summonses in the $51^{\text {st }}$ term, which corresponded with Cardoso's second term. In the $54^{\text {th }}$ legislative term, the last in the period under review, two of the three summonses were directed at this ministry. No request for information was directed at the advisor for International Affairs in this period.

Government-opposition dynamics also seem to have played a major role in the summoning of ministers by Senators. Opposition Senators were responsible for almost twice as many requests for information as those from Senators that formed part of the governing coalition - 88 against 45 . The Ministry of Planning attracted more summonses from government allies, while the Ministries of Agriculture and of Mines and Energy attracted equal numbers. Again, the Ministry of Foreign Relations followed the previous pattern, with more than $80 \%$ of summonses coming from the opposition. The only summons from a committee in that period came from CREDN, and was directed at the Ministry of Foreign Relations.

Our analysis of the use of both tools by the two Houses of the Brazilian Congress shows that the Ministry of the Economy attracted the most attention. The Ministry of Foreign Relations attracted a large number of summonses to ministers, and fewer requests for information, a bit under the average. This points towards a strategy of confronting government role players in person about foreign policy, rather than in writing. Most requests for information and summonses were submitted by members of the opposition. The large number of requests points towards a 'police patrol' approach, as lawmakers tended to question various policies and actions of the executive. Analysing the content of these requests will provide us with further insights into patterns of oversight over foreign policy issues.

\section{Requests and summonses to the Ministry of Foreign Relations}

After analysing the patterns of use of the two tools in question in respect of foreign policy, compared with other policy areas, we will now focus on their substance. This will allow us to determine which foreign policy themes mobilise members of Congress the most, and check whether government and opposition members tend to demand more accountability in some policy areas than others.

Our research shows that general proceedings mobilised members of Congress the most, representing $23 \%$ of all requests and summonses. This category includes questions about contracts, rules for employment and the selection of personnel for Brazilian missions, consular affairs, presidential trips, the maintenance of diplomatic missions, and other issues involving the Ministry's budget. These themes were mostly raised by members of the opposition (74\%). Almost all were requests for information, except for one summons directed at the special advisor for International Affairs. This point to the 'police patrol' approach, with members of the legislature checking proactively whether the executive was playing its role in an effective and responsible way.

Use of both instruments by members of Congress was mobilised by particular events and their treatment in the media. Many requests for information, especially those filed by Senators, were accompanied by extracts from news reports on unfavourable developments, and demanded some action from the executive. This sometimes included other ministries besides Itamaraty. Unsurprisingly, most of these demands came from the op- 
position. This shows that this instrument was used in 'fire alarm' mode, with legislators reacting to events brought to their attention by the media.

The 'fire alarm' mode is also evident in legislators' approach to Latin American issues, such as events in Bolivia, Cuba, Paraguay and Venezuela. These issues started to appear more often in the requests for information. This coincided with increasing criticism by the media of foreign policy towards those countries, which might have been regarded as an opportunity to challenge the government. For example, there were questions about the sales of aircraft to Venezuela, and the assistance of a Brazilian diplomat to the flight of a Bolivian senator. This trend corroborates the idea that these tools are often used in the course of political contestation between the government and the opposition.

Other requests and summonses, although not quoting news articles, were clearly motivated by contemporary events with possible negative consequences for the executive. Again, they represented attempts by opposition members to delegitimise the government, by emphasising controversial aspects of foreign policy. This may explain why some Latin American countries climbed higher in the ranking after 2003. The political debate about Brazilian foreign policy shifted from criticism of an alleged subservient position towards the USA and developed countries in general towards a disapproval of what was seen as excessive rapprochement with leftist governments in Latin America. This speaks to the 'fire alarm' model.

Table 5: Themes of requests and summonses regarding foreign policy

\begin{tabular}{|c|c|c|c|c|c|c|c|c|c|c|}
\hline & \multicolumn{6}{|c|}{ Legislative Term } & \multirow{2}{*}{ Total } & \multirow{2}{*}{ Government } & \multirow{2}{*}{ Opposition } & \multirow{2}{*}{ Committee } \\
\hline & $49^{\text {th }}$ & $50^{\text {th }}$ & $51^{\text {st }}$ & $52^{\text {nd }}$ & $53^{\text {rd }}$ & $54^{\text {th }}$ & & & & \\
\hline General Proceedings & 34 & 32 & 29 & 44 & 22 & 28 & 189 & $21.7 \%$ & $74.6 \%$ & $3.7 \%$ \\
\hline United States & 3 & 13 & 19 & 18 & 4 & 2 & 59 & $32.2 \%$ & $57.6 \%$ & $10.2 \%$ \\
\hline Bolivia & 1 & 1 & 2 & 8 & 12 & 17 & 41 & $22.5 \%$ & $65 \%$ & $12.5 \%$ \\
\hline Security & 4 & 3 & 5 & 11 & 9 & 5 & 37 & $16.2 \%$ & $64.9 \%$ & $18.9 \%$ \\
\hline Venezuela & 6 & 0 & 0 & 5 & 11 & 15 & 37 & $13.9 \%$ & $66.7 \%$ & $19.4 \%$ \\
\hline Trade & 2 & 7 & 13 & 10 & 4 & 1 & 37 & $32.4 \%$ & $56.8 \%$ & $10.8 \%$ \\
\hline Environment & 8 & 5 & 0 & 4 & 12 & 3 & 32 & $34.4 \%$ & $59.4 \%$ & $6.3 \%$ \\
\hline Amazon & 0 & 3 & 2 & 8 & 2 & 1 & 16 & $56.3 \%$ & $31.3 \%$ & $12.5 \%$ \\
\hline International Organizations & 1 & 3 & 5 & 2 & 3 & 1 & 15 & $13.3 \%$ & $73.3 \%$ & $13.3 \%$ \\
\hline Cuba & 1 & 2 & 0 & 3 & 4 & 4 & 14 & $0 \%$ & $85.7 \%$ & $14.3 \%$ \\
\hline Human Rights & 3 & 0 & 2 & 1 & 2 & 6 & 14 & $7.1 \%$ & $85.7 \%$ & $7.1 \%$ \\
\hline Argentina & 3 & 1 & 1 & 5 & 1 & 2 & 13 & $30.8 \%$ & $61.5 \%$ & $7.7 \%$ \\
\hline Paraguay & 1 & 1 & 1 & 1 & 6 & 2 & 12 & $25 \%$ & $66.7 \%$ & $8.3 \%$ \\
\hline Iran & 1 & 0 & 2 & 0 & 7 & 2 & 12 & $16.7 \%$ & $75 \%$ & $8.3 \%$ \\
\hline Europe & 2 & 1 & 3 & 2 & 0 & 4 & 12 & $33.3 \%$ & $50 \%$ & $16.7 \%$ \\
\hline Foreign Firms & 0 & 2 & 2 & 1 & 5 & 0 & 10 & $20 \%$ & $70 \%$ & $10 \%$ \\
\hline Health & 1 & 1 & 1 & 1 & 0 & 6 & 10 & $22.2 \%$ & $66.7 \%$ & $11.1 \%$ \\
\hline China & 0 & 1 & 1 & 3 & 2 & 3 & 10 & $10 \%$ & $60 \%$ & $30 \%$ \\
\hline Total & 100 & 88 & 113 & 171 & 155 & 130 & 757 & $24.1 \%$ & $66.4 \%$ & $9.4 \%$ \\
\hline
\end{tabular}


Table 5 shows that the foreign country which featured most prominently in questions and summonses was the USA. For example, many requests for information in the 1990s centred on the international status attributed to the Amazon in US schoolbooks. The 2002 Brazilian election resulted in a change not only in the number of requests for information involving the USA by members of Congress, but also in their source. In the first three legislative terms, most were filed by the opposition (72\%), but in the latter three, most were filed by members of the government coalition (56\%). Representatives of two parties - the PT and the Communist Party of Brazil - were responsible for more than $41 \%$ of those requests. In terms of content, there was no discernible trend throughout the period under analysis. Recurring themes included negotiations over the Free Trade Area of the Americas; trade issues, such as barriers to trade or trade negotiations; the presence of US companies or government bodies in Brazil; and the Amazon.

Bolivia and Venezuela were mentioned in requests more often than the USA, increasingly significantly during the last three legislative terms. This pattern is also visible in respect of Cuba. As noted previously, questions about these three countries mostly came from the opposition (67\%), with the PSDB the source of most demands for information about these countries (27\%). In terms of content, requests and summonses involving Bolivia, Cuba and Venezuela present a pattern of recurrence of seasonal themes.

Reasons for summoning the minister included suspicions of ties between the governments of those countries and left-wing groupings - notably the Landless Workers Movement - and political parties in Brazil. Questions were asked about relations with those countries and about concurrent steps taken by their governments, as reflected in important shifts and changes in the period under review. Besides the ideological affinity between the presidents of these countries and the PT, members of the opposition focused their attention on and strongly criticised negotiations about regional organisations and energy supply. Energy, trade, defence, assistance to imprisoned citizens, accession to Mercosur, and diplomatic incidents were recurring themes.

Two themes stood out in questions about foreign policy: security and trade. Both were raised most often by opposition members of Congress. While most requests for information about trade came from the PSDB and PT, no patterns were discernible in respect of security. While trade included questions about multilateral negotiations and responses to protectionist actions by various trade partners, security encompassed a range of themes, including terrorism, drug trafficking, cyber activity, human trafficking, weapon trade, and the protection of national borders and the sea.

Requests for information and the summoning of ministers were used for different themes, probably because the two tools represent different strategies. Most requests for information were about Itamaraty's general proceedings, followed distantly by the USA, while the most common reasons for summoning the minister or special advisor were issues involving Bolivia and Venezuela. Requests for information often reflected the 'police patrol' model, as topics that did not feature prominently in political debates were addressed. The use of summonses conformed mostly to the 'fire alarm' model, with lawmakers focusing on inviting ministers to explain their actions in respect of controversial contemporary issues. 
While the PSDB and PT were important users of requests for information, the PSDB in opposition was responsible for $43 \%$ of summonses directed at the Ministry of Foreign Relations. While members of the opposition exhibited both 'police patrol' and 'fire alarm' behaviour in overseeing foreign policy, government members concentrated on a 'police patrol' approach.

Members of both Houses focused mostly on general proceedings. However, Senators tended to focus on Bolivia and Venezuela, while Deputies focused on a wider range of themes. The weight of the opposition in the requests by Deputies is considerably stronger than among those made by Senators. Senators tended to adopt the 'fire alarm' approach, focusing on issues after they had become controversial, while, due to their larger numbers, Deputies raised a broader range of issues, not only those in the headlines, thereby combining both approaches.

The foregoing analysis of requests for information and the summoning of government role players in respect of international relations point to interesting conclusions. These two tools were systematically used to challenge the executive and to exercise some oversight over the general activities of the Ministry of Foreign Relations, thus conforming to the 'police patrol' model. Strongly influenced by conjunctural events, many requests and summonses were triggered by controversial aspects of Brazilian foreign policy, including influences exercised by foreign governments or parties, with lawmakers acting in a 'fire alarm' mode.

The shifts in the prevalence of themes through the period under review were strongly influenced by ideological factors, notably party affiliations. Most of the debates about Itamaraty triggered by questions or summonses served to challenge foreign policy for ideological or party-political reasons. Technical aspects of foreign policy-making and questions about the general state of Brazil's relations with the world were overshadowed by the government-opposition divide.

\section{Final remarks}

Recent discussions of the role played by parliaments in foreign policy have pointed to the need for comparative analyses. However, research until now has concentrated on countries in the Global North, inviting efforts to buck this trend. This article sought to do so, and to shed light on the Brazilian case. It benefited from ongoing research on other instruments used by Brazilian lawmakers to oversee foreign policy.

The analysis of requests for information and summonses to ministers filed by Brazilian Senators and Deputies between 1991 and 2014 provide some interesting insights into the role played by the legislative branch in respect of foreign policy. Bearing in mind the relevant provisions of the 1988 Constitution, these two instruments have allowed members of Congress to challenge international strategies pursued by the Presidency, and to encourage it to address other issues. The subjects of these requests changed significantly in 2003 after the Workers' Party came to power, with Bolivia and Venezuela edging out the USA as the main areas of concern. 
The Ministry of Foreign Relations did not attract undue attention. However, there were more summonses than requests for information, which shows that members of Congress preferred to discuss foreign policy issues instead of simply receiving answers to specific questions. Use of both instruments in respect of foreign policy conformed to the 'police patrol' model. However, there were moments where the 'fire alarm' approach prevailed, especially at times of contestation among opposition members.

The data also shows that the Brazilian legislature treated foreign policy like other themes. This corroborates the findings of other analyses of oversight mechanisms. Although there is room for particularities, foreign policy is not relegated to a minor position on the legislative agenda.

To conclude, we hope our research will help voters to understand that their representatives form an integral part of decision-making about foreign policy, and will also encourage further comparative research.

\section{Notes}

1. Ongoing research on this subject has identified only four cases of rejection of the nomination of authorities since the beginning of the 49th legislative term. Only one of these was about an ambassador.

2. Senators and Deputies did not summon ministers every year in every legislative term. Therefore, there are years in the analysis that have no data.

3. Marco Aurélio Garcia, former member of the Workers' Party and History professor at the University of Campinas, served as Special Advisor to the Presidency for International Affairs during the administrations of Luís Inácio Lula da Silva and Dilma Rousseff (2003-2016). His role in the formulation of Brazilian foreign policy during this period involved a series of issues which were raised by the opposition to discredit the government's international strategy.

\section{References}

Abranches, S. 1988. 'Presidencialismo de Coalizão: O Dilema Institucional Brasileiro' Revista de Ciências Sociais 31 (1): 5-34.

Amorim Neto, O and P Tafner. 2002. 'Governos de Coalizão e Mecanismos de Alarme de Incêndio no Controle Legislativo das Medidas Provisórias.' Dados 45 (1): 5-38.

Anastasia, F, C Mendonça and H Almeida. 2012. 'Poder legislativo e política externa no Brasil: Jogando com as Regras.' Contexto Internacional 34 (2): 617-657.

Batjay, P. 2015. 'Democratic and efficient foreign policy? Parliamentary diplomacy and oversight in the $21^{\text {st }}$ century and the post-Lisbon role of the European Parliament in shaping and controlling EU foreign policy. EUI Working Papers 11.

Brazil. 2016. Constituição da República Federativa do Brasil. Brasília: Palácio do Planalto. At http:// www.planalto.gov.br/ccivil_03/constituicao/constituicao.htm [Accessed on 19 April 2018].

Chamber of Deputies. 2012. Regimento Interno da Câmara dos Deputados. Brasília: Chamber of Deputies.

2018. Atividade Legislativa: Projetos de lei e outras proposições. At http://www.camara.leg.br/ buscaProposicoesWeb/pesquisaSimplificada [Accessed on 20 April 2018]. 
Cox, G W and S Morgenstern. 2001. 'Latin America's Reactivee Assemblies and Proactive Presidents.' Comparative Politics 33 (2): 171-190.

Diniz, S. 2009. 'Atos internacionais e atuação do legislativo.' Teoria \& Pesquisa XVIII: 27-59.

Diniz, S and C Ribeiro. 2008. 'The role of the Brazilian Congress in foreign policy'. Brazilian political science review 2: 10-28.

European Parliament. 2015. Shaping and controlling foreign policy: Parliamentary diplomacy and oversight, and the role of the European Parliament. Brussels: European Parliament.

Federal Senate. 2011. Regimento Interno do Senado Federal: Resolução n. 93, de 1970. Brasília: Federal Senate.

2018. Atividade Legislativa: Projetos e Matérias. At http://www25.senado.leg.br/web/atividade/materias [Accessed on 20 April 2017].

Figueiredo, A and F Limongi. 1999. Executivo e Legislativo na Nova Ordem Constitucional. Rio de Janeiro: FGV.

Fowler, L. 2015. Watchdogs on the Hill: The Decline of Congressional Oversight of U.S. Foreign Relations. Princeton: Princeton University Press.

Gaylord, S. 2010. 'Delegation and Defencive Legislative Strategies in Brazil.' Legislative Studies Quarterly 35 (1): 5-30.

Herbel, A. 2016. 'Parliamentary scrutiny of the EU's Common Foreign and Security Policy.' West European Politics 40 (1): 161-182.

Jensen, C B, S Proksch and J B Slapin. 2013. 'Parliamentary Questions, Oversight, and National Opposition Status in the European Parliament.' Legislative Studies Quarterly 38 (2): 259-282.

Kaiser, F. 1977. 'Oversight of Foreign Policy: The U. S. House Committee on International Relations.' Legislative Studies Quarterly 2 (3): 255-279.

. 1988. 'Congressional Oversight of the Presidency.' The Annals of the American Academy 499: 75-89.

Lagassé, P and S M Saideman. 2016. 'Public critic or secretive monitor: party objectives and legislative oversight of the military in Canada.' West European Politics 40 (1): 119-138.

Lemos, L B de Sousa. 2005a. 'Como o Congresso brasileiro controla o Executivo? O uso de requerimento de informação, convocação de autoridades e propostas de fiscalização e controle.' In M Llanos and A M Mustapic (eds), Controle parlamentar na Alemanha, na Argentina e no Brasil. Rio de Janeiro: Konrad Adenauer Stiftung, pp. 85-112.

2005b. 'Controle Legislativo em Democracias Presidencialistas: Brasil e EUA em perspectiva comparada.' PhD Thesis, Universidade de Brasília, Brazil.

Paper 58.

2010. 'Brazilian Congress and Foreign Affairs: Abdication or Delegation?' GEG Working

Lemos, L B de Sousa and M Llanos. 2008. 'On Reactive Legislatures: The Politics of Presidential Nominations in Argentina and Brazil (1989-2003).' Revista Brasileira de Ciências Sociais 4 (special issue): $0-0$.

Lemos, L B de Sousa and T J Power. 2013. 'Determinantes do Controle Horizontal em Parlamentos Reativos: O Caso do Brasil (1988-2005).' Dados 56 (2): 383-412. 
Lima, M R S and F Santo. 2001. 'O Congresso e a Política de Comércio Exterior'. Lua Nova 52: 121149.

Lin, N C. N. 2015. 'Informative Committees and Legislative Performance in the American States.' Legislative Studies Quarterly 40 (3): 391-415.

Llanos, M and A M Mustapic. 2005. 'Introdução: O controle parlamentar na Alemanha, na Argentina e no Brasil.' In M Llanos and A M Mustapic (eds), Controle parlamentar na Alemanha, na Argentina e no Brasil. Rio de Janeiro: Konrad Adenauer Stiftung, pp. 9-24.

Lupia, A. 2003. 'Delegation and its Perils' In K Ström, W Müller and T Bergman (eds), Delegation and accountability in parliamentary democracies. New York: Oxford University Press, pp. 33-54.

McCubbins, M and T Schwartz. 1984. 'Congressional Oversight Overlooked: Police Patrols versus Fire Alarms.' American Journal of Political Science 28 (1): 65-179.

Mello, P A and D Peters. 2018. 'Parliaments in security policy: Involvement, politicisation, and influence.' The British Journal of Politics and International Relations 20 (1): 3-18.

Otkay, S. 2018. 'Chamber of opportunities: Legislative politics and coalition security policy'. The British Journal of Politics and International Relations 20 (1): 104-120.

Pereira, C, and L Rennó. 2013. 'Should I Stay or Should I Go?: Explaining Political Ambition through Electoral Success in Brazil.' Journal of Politics in Latin America 5: 73-95.

Raunio, T. 2014. 'Legislatures and Foreign Policy.' In S Martin, T Saalfeld and K W Strøm (eds), The Oxford Handbook of Legislative Studies. Oxford: Oxford University Press, pp. 1-28.

Raunio, T and W Wagner. 2016. 'Towards parliamentarisation of foreign and security policy?' West European Politics 40 (1): 1-19.

Santos, M H de Castro. 2005. 'Controles parlamentares e os militares no Brasil: audiências públicas e requerimentos de informação, 1995-2004.' In Mariana Llanos, and A M Mustapic (eds), Controle parlamentar na Alemanha, na Argentina e no Brasil. Rio de Janeiro: Konrad Adenauer Stiftung, pp. 113-140.

Silva, A L R da, and A P Spohr. 2016. 'A relação entre executivo e legislativo na formulação de política externa no Brasil.' Relações Internacionais 50: 123-140.

Silva, R S. 2012. A Política Externa Brasileira Analisada em Três Dimensões: Um Estudo sobre a Comissão de Relações Exteriores e de Defesa Nacional da Câmara dos Deputados. Masters Dissertation., Universidade Federal de Pernambuco, Brazil.

Smulovitz, C and E Peruzzotti. 2003. 'Societal and Horizontal Controls: Two Cases of a Fruitful Relationship'. In S Mainwaring (ed), Democratic Accountability in Latin America. Oxford: Oxford University Press, pp. 309-333.

\section{Acknowledgments}

This study was financed in part by the Coordenação de Aperfeiçoamento de Pessoal de Nível Superior - Brasil (CAPES) - Finance Code 001. 


\section{About the authors}

Alexandre Piffero Spohr is a PhD student in Political Science at the Federal University of Rio Grande do Sul (UFRGS) in Brazil. He holds a Master's Degree in Political Science, and a Bachelor Degree in International Relations. He researches Brazilian foreign policy analysis and development. His research interests include emerging powers, foreign policy analysis, and international political economy, aiming to combine those fields of study to allow for a deeper and more comprehensive approach to international relations. He is currently participating in a project on Brazilian foreign policy, and his doctoral research centres on Brazilian foreign policy decision-making processes, with a special focus on the role played by the Brazilian National Congress.

André Luiz Reis da Silva holds a PhD in Political Science from the UFRGS. He is Associate Professor and Dean of the Graduate Programme in International Strategic Studies at the same university, and Editor-in-Chief of Conjuntura Austral: Journal of the Global South. Previously, he was a post-doctoral fellow at the School of Oriental and African Studies (SOAS) of the University of London (2013). He researches the international relations of Southern countries, focusing on Brazilian foreign policy and emerging powers in Asia and Africa. One current research project is focused on Brazilian and Turkish foreign policy in comparative perspective, and another on the foreign policy of Dilma Rousseff's government. He holds a CNPq Productivity Fellowship (level 2). 


\title{
Supervisão Legislativa da Política Externa Brasileira: uma Análise de Pedidos de Informação e Convocações de Ministros, 1991-2014
}

\begin{abstract}
Resumo: Este artigo tem como objetivo identificar como o Congresso Nacional brasileiro supervisiona a tomada de decisões em política externa. Ao responder se os senadores e deputados fazem uso de seus instrumentos de supervisão de maneira diferente quando lidam com política externa, pretende apresentar as particularidades desse processo para os tópicos de política externa e o padrão de supervisão que prevalece: alarme de incêndio ou patrulha policial. Essa pesquisa tem por objeto os pedidos de informações e convocações de ministros interpostos pela Câmara dos Deputados ou pelo Senado Federal entre 1991 e 2014, especialmente os dirigidos ao Ministério das Relações Exteriores. Ao comparar o uso dessas ferramentas para esse ministério com o modo como elas são usadas para lidar com outras questões, podemos confirmar suas semelhanças com o processo geral de supervisão no sistema político brasileiro. A análise do conteúdo de tais solicitações nos fornece observações interessantes sobre o uso político dessas ferramentas, especialmente em termos da divisão entre governo e oposição.
\end{abstract}

Palavras-chave: Política Externa Brasileira; Estudos Legislativos; Supervisão do Congresso; Pedidos de Informações; Convocações de Ministros.

Received on 16 June 2018, and approved for publication on 27 August 2018. 